\title{
Next EUROSON Congress
}

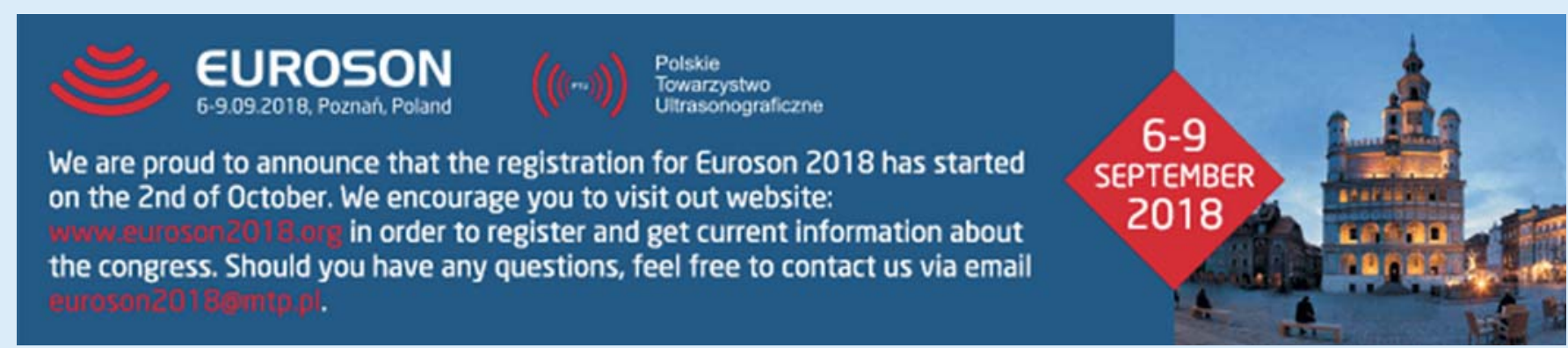

www.euroson2018.org

IMPORTANT DATES

Online registration:

2.10.2017
Very early bird registration:

2.10.2017-1.02.2018

Early bird registration:

2.02.2018-1.06.2018

Regular registration:

2.06.2018-9.09.2018

\section{Abstract Submission:}

2.01.2018-15.06.2018

First announcement:

December 2017 